\title{
COPENHAGEN POLITICAL CRITERIA AND \\ TURKEY'S NATIONAL PROGRAMME FOR THE ADOPTION OF THE EU ACQUIS ${ }^{*}$
}

\section{Volkan BOZKIR**}

\author{
Dear Minister, \\ Dear President of Marmara University, \\ Dear Director of the Board of the Istanbul Chamber of Industry and Dear \\ Members of ICI, \\ Dear Guests, \\ Dear Members of the Press,
}

I feel great pleasure at being present here today and finding an opportunity to share my opinions with you about the latest developments on the current topic of discussion in Turkey, namely full-membership in the European Union. It is especially meaningful that this conference is being organized by the European Community Institute of Marmara University within the framework of "Europe Day".

Turkey's relationship with the European Union has a long history. 43 years have passed since our first application to the European Economic Community. Turkey has considered membership to the European Economic Community, the European Community and the European Union respectively as an important step in attaining the end goal of reaching contemporary civilization and even surpassing it, which is the basic desire and aim of our Republic. Despite ups and downs, Turkey has directed her efforts

* Speech for the international conference entitled "The Future of the European Union and Turkey" organized by the European Community Institute of Marmara University on the occassion of the Europe Day, 9 May 2002.

** Deputy Secretary General for EU Affairs, Prime Ministry of Turkey. 
continuously and with determination to attaining the goal of full-membership during these past 43 years. Turkey acquired an associate member status with the European Union via the Ankara Agreement of 1963 and signed the Customs Union in 1996.

First of all, I would like to mention the belief existing in our public opinion that 'Europe has refused to acknowledge Turkey's full-membership applications until now'. On the contrary, when past developments in Turkish-EU relations are considered, it can be observed that Turkey has hitherto been the side that had demanded delay at critical moments of decision. One of the most important underlying reasons for this fact is that Turkey did not feel ready for full-membership in the economic, social and political sense until now. It is important to remember that Turkey's exports in the 1970s comprised only 4 agricultural products and amounted to 2.5 billion dollars. They did not even correspond to the imports of petrol and it was not even possible to mention a free market economy. Yet, Turkey is now ready for EU membership in every sense, with a trade volume of 70 billion dollars, exports comprising more than 4000 industrial products and an economic structure completely compatible with the principles of the free market economy. Therefore, Turkey has for the first time received an opportunity to test the intentions of the European Union concerning Turkey's accession.

Turkey is now at the point where she is closest to full-membership, following the confirmation of Turkey's candidacy to the European Union at the Helsinki Summit in 1999. Besides the Association Agreement the EU has concluded with our country, the Union has also taken considerable steps to free Financial Cooperation from political interference and to place this cooperation within a single framework. The legal steps of the pre-accession strategy were completed upon the ratification of the National Program on 19 March 2001 by the Turkish Government and Turkey's candidate status has then acquired an official dimension.

Now, the ball is in Turkey's court and her performance will be the key to full-membership. At this point, the priority of our government is to start fullmembership negotiations as soon as possible. Starting full-membership negotiations is a political decision that the European Union will make. The fundamental factor affecting this decision is the successful fulfillment of 
both the political criteria stated in the National Program and the expectations mentioned in the Association Partnership Document.

The constitutional amendments achieved in 2001 serve as the basis for our harmonization efforts regarding the political criteria. The guarantees for individual rights and freedoms have been increased as a result of these constitutional amendments. In particular, the scope for freedom of thought and expression has been extended. Custody has been limited to 4 days in compliance with European Union standards, in order to prevent the possibility of torture Various arrangements have also been made to improve gender equality.

The harmonization codes that will make these constitutional amendments applicable are being enacted. The new Civil Code, implemented in January 2002, has been an important turning point in efforts to reflect these constitutional amendments in our laws and regulations. The new Civil Code serves as a fundamental law in terms of harmonization with the Copenhagen political criteria.

Considerable amendments were made in laws such as the Turkish Criminal Law, the Anti-Terror Law, the National Security Court Law, the Act on Criminal Procedures in conformity with the Harmonization Law, ratified in February 2002.

The second wave of the Harmonization Law was ratified in March 26. Thereby, important amendments have been achieved in laws concerning the Political Parties, the National Security Court, the Gendarmarie and City Regulation.

These are not the only amendments regarding laws and regulations realized in order to comply with the EU acquis Turkey is trying to enact a new Turkish Criminal Law, a new Act on Criminal Procedures, an Act on the Radio Television Supreme Board and laws concerning Associations and Public Meetings and Demonstrations.

Keeping the above facts in mind, it can be stated that Turkey has completed her assumed responsibilites with respect to the political criteria except for four fundamental issues. 
These four issues are:

- the abolition of the death penalty,

- the removal of obstacles preventing Turkish citizens from radio and TV broadcasting in their own minority language,

- allowing Turkish citizens to learn their minority language,

- abolition of the Extraordinary Circumstance regulation still existing in 4 cities.

At the end of this year, the European Union is probably going to declare ten candidate countries ready for accession as full-members from 2004 onwards. All candidate countries except Turkey will become full-members of the Union in the following 4-5 years. All these decisions will be made at the Copenhagen Summit which is to take place at the end of 2002.

The speed and the dynamics of this enlargement wave means it is necessary for Turkey to request a more open and clear timetable on the road to full-membership as such decisions are also being taken for the other candidate countries.

On the other hand, we should satisfactorily accomplish our own responsibilities and keep the promises stated in our National Program as soon as possible in order to be in a position to request a specific timetable from the European Union.

Turkey is expected to support initiatives aimed at finding a political solution to the ongoing problems in Cyprus. Even though the Cyprus issue is not among the political criteria for full-membership, it is an important factor regarding Turkey's relations with the European Union. We hope that the negotiations between the leaders of the two societies will be completed successfully. Yet, it would be wrong to expect the Greek Cypriot Side to incline towards any solution if no pressure is exerted upon the Greek Cypriot Administration on this issue. If the Greek Cypriot Administration is not eager to find an acceptable and sustainable solution with the Turkish Republic of Northern Cyprus within the guarantee of full-membership to the European Union, then the European Union would be responsible for such failure. However, we expect the Greek Cypriot Administration to provide the necessary contribution to the positive resolution of the negotiations, without 
making the mistake of considering the long-standing stalemate as a preferable solution for their side.

The steps that Turkey has taken over the last year are of considerable importance in meeting the Copenhagen political criteria.

This has been achieved with an open-ended understanding of reconciliation. I believe that Turkey can make the expected moves to start full-membership negotiations with the same understanding of reconciliation. 